Western Washington University Western CEDAR

\title{
An Illustration of the Quest Genre as Spiritual Metaphor in Adventure Travel Narratives
}

Jasmine M. Goodnow

Western Washington University, jasmine.goodnow@wwu.edu

Edward Ruddell

University of Utah

Follow this and additional works at: https://cedar.wwu.edu/healthandhumandev_facpubs

Part of the Health and Physical Education Commons

\section{Recommended Citation}

Goodnow, Jasmine M. and Ruddell, Edward, "An Illustration of the Quest Genre as Spiritual Metaphor in Adventure Travel Narratives" (2009). Health and Human Development. 2.

https://cedar.wwu.edu/healthandhumandev_facpubs/2

This Article is brought to you for free and open access by the Social and Behavioral Sciences at Western CEDAR. It has been accepted for inclusion in Health and Human Development by an authorized administrator of Western CEDAR. For more information, please contact westerncedar@wwu.edu. 


\title{
An Illustration of the Quest Genre as Spiritual Metaphor in Adventure Travel Narratives
}

\author{
Jasmine M. Goodnow \\ Western Washington University \\ Edward Ruddell \\ University of Utah
}

Contact: Dr. Jasmine Goodnow, Western Washington University 360-650-2393,goodnoj@wwu.edu 
Quest Genre as Spiritual Metaphor in Adventure Travel Narratives 2

An Illustration of the Quest Genre as Spiritual Metaphor in

Adventure Travel Narratives

\begin{abstract}
Adventure travel narratives are often written within a quest genre. The quest as genre is a romantic narrative that follows a pattern of sequential steps: the call to journey, preparation, the journey, and returning home. This paper proposes that the quests in which adventure travelers embark upon are spiritual in nature. Therefore, the quest genre is a metaphorical vehicle for narrating a spiritual journey. The term "spiritual," in this context, refers to connecting to something outside of oneself. The purpose of this paper is to describe adventure travel as spiritual questing and to illustrate this idea with three popular adventure travel narratives. It is important to understand the common themes and constructions within adventure travel narratives because of their ability to frame travel expectations and influence various factors in the travel and tourism industry (trip choice, travel mode, destination choice, and intention to travel).
\end{abstract}

Keywords: adventure travel, spiritual quest, quest genre, reverence 
An Illustration of the Quest Genre as Spiritual Metaphor in Adventure Travel Narratives

Adventure travel has been described as journeys that

take people to mountaintops, tropical forests, deserts, and the Arctic, as well as into the air and under the sea. People endure hardships during long travel and in lonely places devoid of modern comforts. They willingly encounter heat, cold, and insects to find outdoor adventure and challenge. (Jensen, 1985, p. 15)

What is this drive that calls people out of their comfortable homes and into strange and often difficult environments? Thrill-seeking and risk are often rated as the strongest motives for adventure travel (Ewert \& Hollenhorst, 1989; Griffith \& Albanese, 1996; Hill, 1995; Plog, 1991; Priest, 1992; Robinson, 1992; Sung, Morrison, \& O’Leary, 1996). Yet, adventure travel narratives, books that adventure travelers write themselves, chronicle experiences that seem to serve as vehicles for spiritual questing. Travel writing is generally described as a "factual, first-person account of a journey undertaken by the authors" (Hooper \& Youngs, 2004, p. 2). Travel narratives follow a particular pattern or structure that is linear and chronological, written in the form of a memoir or novel (Dann, 1999) with a trend toward self-discovery, and the use of the metaphors of hero's quest and inner journey (Borella, 2006; Thursby, 2005). Dann (1999) describes the quest romance as being

based on the idea of a hero setting out, experiencing trials and adventure, and returning home victorious and changed...Here the myth has been displaced by the traveler as a puny alien crawling over a territory with no roots, then returning to discover his/her true self. Thus, the travel book, as a type of successful literary performance, is a happy blend of reportage and parable, of landscape plus incident doing the symbolic work of fable. (p. 164) 
The quest often looks like a treasure hunt (Groom, 2005) where the traveler searches for treasures in the form of self, spirituality, freedom, and life's meaning and direction.

Thus, the purpose of this paper is to describe how adventure travel narratives are a part of the popular narrative genre called the "quest" and that adventure travel narratives illustrate adventure travel as a vehicle for spiritual questing. This paper will provide a brief literature review regarding travel narratives, quest genre, and spirituality. Following the review of literature, three adventure travel narratives will be used to provide textual evidence illustrating the quest genre and its role in spiritual questing.

\section{Literature Review}

\section{Travel Narratives}

Entire sections of bookstores and libraries are dedicated to personal travel accounts of modern-day travelers such as Michael Palin's (1997) Full Circle and Bill Bryson's (1997) A Walk in the Woods, both of which were national best sellers (Dann, 1999). Furthermore, a study conducted by Wilson \& Richards (2004) identified that "the range of books read by travelers is vast: more than 200 titles were being read 'on the road"' (p. 127). The writers most frequently mentioned as influential by travelers were: Ernest Hemingway, Jack Kerouac, Hunter S. Thompson, Bruce Chatwin, Paul Theroux, Bill Bryson, and Michael Palin.

Travel narratives have influenced culture as early as the tenth century and continue to influence and inform the public to this day. Many modern-day travelers are inspired by published travel narratives to live vicariously through reading about the travel experiences of others, and some are inspired to embark on journeys of their own (Wilson 
\& Richards, 2004). "The simple, adventurous life described by Hemingway is so attractive to contemporary readers that many travel to recreate the Hemingway experience" (Wilson \& Richards, p. 130). Travel narratives have influenced not just the decision to travel or take a holiday/vacation (Clough 1997; Dann, 1996, 1999; Wilson \& Richards), but have influenced travel destination choice, travelstyle (accommodation type, mode of travel, solo/group, independent/package tour), self-representations, and aspirations of their readers (Wilson \& Richards).

Travel writing impacts the popularity of both discovered tourism destinations as well as undiscovered ones. Once a travel narrative highlights a destination, these oftenundiscovered places are transformed into discovered or popular tourist destinations (Wilson \& Richards, 2004). Travel writing increases tourist visits and may provide the catalyst to tourism infrastructure development to accommodate the increase in tourism demand. Thus, travel writing is a significant promotional device and may be responsible for "setting the agenda of the tourist experience" (Dann, 1999, p. 161). It is important to understand public discourse and the influence of travel narratives on both the travel industry and those people who read adventure travel narratives.

Published travel narratives may be viewed as an underutilized source of travel and tourism knowledge. It is important to attend to the influences that are not controlled by the travel and tourism industry, but may affect the industry itself. It is quite possible that travel narratives, to the extent that they help to shape and develop personal expectations, as well as become a part of one's personal base of experience, play a role in how travel is engaged in and experienced by individuals. In fact, Fullagar (2001) has recently commented on just this possibility: "The growing genre of realist and fictional travel 
narratives offers itself up to textual forms of analysis that can contribute to a deeper theorizing of tourism as a broad interdisciplinary field" (p. 5). Travel narratives may inform and influence potential travelers, the tourism industry, and the public at large. It is important to understand how literature, in the form of adventure travel narratives, influences travelers' destination choice, mode of travel, as well as its ability to frame the travel experience and expectations of travelers.

\section{Quest Genre}

A genre is a well-established pattern of discourse. The quest as genre is a romantic narrative in which individuals with some sort of spiritual vision are compelled to journey for that which is sacred and along the way perform heroic deeds (Campbell, 1968; Dispenza, 2002; McAvoy \& Dustin, 1989). As the quest unfolds hazards are negotiated and overcome, usually with great difficulty. There are often lengthy descriptions of the adventurer's character and his or her life before the journey. Questers are commonly characterized as being somewhat antisocial because they are so focused on their spiritual vision. Additionally they may be outcasts, solitary figures, and may have a mysterious connection to nature. Within the quest narrative, there is also a description of how the seeker's vision unfolds and a description of the seeker's training for the quest. Although sometimes misinterpreted as adventure-laden entertainment, the quest genre is a metaphorical vehicle for narrating a spiritual journey.

Quest-genred narratives typically open with a call to journey (Campbell, 1968; Dispenza, 2002) and describe the traveler feeling a need to seek something outside of oneself: 
The call to journey is the insistent, irresistible pull of our Higher Selves, inviting us to go to the next step, to rise to the next level of ourselves...it is a literal call to make a trip somewhere...We use the term 'wake-up call' to describe the sudden summons to stop living with illusions, to take better care of ourselves, or to alter our behavior in some basic way. The call may be something as fundamental as the abrupt realization that certain areas of our lives have become intolerable. (Dispenza, pp. 24-25)

Before and during the call to journey, travelers often write of feelings of disillusionment with their lives and the longing for something more meaningful, "real," or something more akin to "truly living." The feelings of disillusionment illustrate the need to seek something spiritual. As the disillusionment unfolds, the seeker/traveler's unique character is brought to light. Conflict with important others over the travel adventure (usually involving leaving a comfortable life, leaving an impressive job, and/or leaving family and friends behind) shows the traveler/seeker to be a misunderstood and sometimes solitary or anti-social person.

Travel narratives suggest that if one accepts the call to journey, then the second stage of preparation occurs (Campbell, 1968; Dispenza, 2002; McAvoy \& Dustin, 1989). Preparing for the journey includes determining and accumulating the material possessions, the physical ability, and the emotional strength that will be needed throughout the journey. Material possessions include the necessary clothing, money, food, and shelter that will be required for a successful journey. Will the journeyer need to provide her own shelter such as a tent, or will she need money to purchase a room along the way? What type of clothing will be needed to protect oneself from the weather and environment, and where will one find the food for sustenance? High levels of physical ability and endurance are needed for journeys including trekking, kayaking, or other forms of self-propelled travel. Physical training occurs during the preparation stage, and 
many travelers engage in training regimens that begin months and sometimes years before the actual journey begins. Psychological training occurs during the preparation stage as well. Gaining emotional strength includes: building one's sense of courage and purpose; reaffirming the goal of the journey; and answering the call of one's spiritual vision. Within this preparation stage a helper/guide emerges to give advice and offer protection (Campbell, 1968; McAvoy \& Dustin).

The third phase of the quest pattern is the journey itself (Campbell, 1968; Dispenza, 2002; McAvoy \& Dustin, 1989). Travelers leave the safety, security, and routine of daily life embarking to sometimes dangerous, uncomfortable, and uncertain places. It is here in the quest genre that hazards are negotiated and, with difficulty, overcome. No spiritual goal is attained without effort. The tie here to apophatic mysticism is tempting. Apophatic mysticism emphasizes the importance of ascetic experiences as emptying. The idea is that one cannot connect to something outside of oneself if one's self is in the way. Christ (1980) describes this concept as the "dark night" and as a "metaphor for the sense of emptiness" (p. 14). Christ further suggests that emptying is not paralyzing; instead it is liberating. The purpose of simplicity and hardship is to become an empty vessel so that one can be filled with something new. Some specific tests that occur include "confronting personal fears, weather, terrain, physical labor and discomfort” (McAvoy \& Dustin, 1989, p. 41).

After the ascetics of travel, the traveler is now open and discovers a different "world" than the one previously known. Self-perceptions and one's place in the world shift, and insights or deeper understandings of one's purpose in life represent the traveler/seeker's spiritual attainment. Dispenza (2002) described journeys as “always 
about going from where we are now to another place. We go literally, but we can also travel figuratively as we search for another, higher level of consciousness. Seen this way, all our travel has a spiritual character" (p. 14).

Following the journey, the traveler returns home and recounts the tale of the journey, completing the final stage of the quest. Recounting the tale solidifies the experience of travel, the lessons learned, the mysteries discovered, and the higher spiritual level attained. The telling of the tale, creating one's own travel narrative, illustrates not only the pattern of the spiritual quest but elevates the journey "to the level of myth" (Dispenza, 2002, p. 144). Dispenza sums up the pattern of a quest:

The great heroes of mythology left the comforts of home and embarked on epic expeditions into the unknown. The accounts of their travels, celebrated in song and passed down through the centuries, form the wisdom of the ages. In myth, the journey of life is an adventure of unparalleled drama and excitement calling forth courage, integrity, generosity, and endurance- and giving back a deep spiritual understanding. (p. 15)

\section{Spirituality}

Travel narratives are a part of the quest genre (Borella, 2006; Dann, 1999; Dispenza, 2002; Fussell, 1980; Thursby, 2005), however, this paper posits that the quest illustrated in travel narratives is spiritual in nature. Spirituality is a term often associated with very different meanings (Andres, 1997) that may or may not have a religious connotation. Kass, Friedman, Leserman, Zuttermeister, and Benson (1991) identified two characteristic elements of spiritual experiences that seem common to most definitions of spirituality. The first characteristic is "a distinct event and a cognitive appraisal of that event which result[s] in a personal conviction of...some form of higher power" (p. 204). 
The second characteristic of a religious spiritual experience is the sense of a personal relationship with that higher power.

Many descriptions of spiritual experiences include an awareness of a higher power and relationship or connection with that higher power. In a qualitative study, wilderness users described spirituality as feelings of "reverence, respect...interaction with and a relationship to something other and greater than oneself..." (Driver, Dustin, Baltic, Elsner, \& Peterson, 1996, p. 5). Often this higher power is an aspect of nature or of natural processes. McDonald (1989) defines spirituality as "the process of becoming aware of the life present in all forms" (p.19), and McDonald, Guldin \& Wetherhill (1988) define wilderness spirituality as "the sudden or gradual awareness of interrelationships among plants, animals, the landscape, and indeed all naturally-occurring things within [an] environment... 'untrammeled by man"' (p. 194). Fox (1999) defines spirituality as

an altered state of consciousness where an individual may experience a higher sense of self, inner feeling, inner knowledge, awareness and attainment to the world and one's place in it, knowledge of personal relations and the relationship to the environment, or a belief in a power greater than imaginable. (p. 455)

Christ (1980) offers a woman's perspective of a spiritual quest that fits quite nicely with the framework presented in this paper. Christ describes spirituality as a "connection to nature...oneness with the universe" (p. xi), and that "great powers may be revealed through natural forces" (p. 10).

For the purpose of this paper, the term "spiritual" refers to connecting to something outside of oneself and often to something larger than oneself. This definition subsumes all those discussed above allowing "something" to include references dealing with nature, environment, and all forms of higher power. Bloom (2007) suggests that a 
Spiritual process works in a universal manner (Maslow, 1974). The process is marked by a sense of being a part of a larger whole (Chenery, 1984; Fox, 1999; Kaplan \& Talbot, 1983; McDonald \& Schreyer, 1991;

Stringer \& McAvoy, 1992). Additionally, spiritual process contains elements of contemplation (Chenery, 1984); awareness of relationships (McDonald, Guldin, \& Wetherhill, 1988); a sense of peace, clarity, and strength (Stringer \& McAvoy, 1992); and feelings of awe, wonderment, and timelessness (Fox, 1997; Fredrickson \& Anderson, 1999). (p.17)

Spiritual attainments frequently manifest themselves as a greater awareness of self and a re-prioritization of goals and values. Such re-prioritizations may also express themselves, behaviorally, as shifts to a simpler, less harried, less anxious, and more reverent (Woodruff, 2001) lifestyle.

\section{Method}

The purpose of this essay is to illustrate the quest genre in adventure travel narratives and describe how this genre can be interpreted as a rhetoric of spiritual questing of the adventure traveler. This essay explores the quest as a process and a pattern of seeking spiritual attainment but will not focus exclusively on the attainment of spirituality. Three narratives were chosen to illustrate the pattern of the quest genre and the spiritual nature of such a quest. The three narratives were selected from the travel writing section of a national bookstore chain. They were intended to represent a typical adventure travel narrative but were purposively chosen because of the clarity in which they illustrate this idea of questing as a process.

An additional intent is to represent male and female, young and old, and solo and non-solo voices of adventure travelers within three different activity types of adventure journeys (sea kayaking/rowing, hiking, and biking). Fredston (2001) was a middle-aged woman who rowed in Arctic waters with her husband; Fletcher (1989) was a young man who trekked the length of the Grand Canyon; and Mustoe (2002) was a retired woman in 
her sixties who solo bicycled around the world. This selection of adventure travel narratives represents different modes or types of adventure travel, both sexes, and several ages or stages of the lifespan. The purpose of the following discussion is to illustrate the quest genre within adventure travel narratives and to illuminate the spiritual quality of these quests. A textual analysis of each narrative was conducted using the literature review as a guide for making decision rules and identifying text that exemplified the quest genre and spirituality.

\section{Adventure Travel Narratives}

\section{Fredston: Rowing to Latitude}

Rowing to Latitude (Fredston, 2001) is one example of an adventure travel essay as a form of spiritual quest. Every summer, Jill Fredston and her husband rowed away from their secure and predictable ordinary life into the harsh Arctic Ocean of solitude, risk, and discovery. There, in that environment, they conducted their spiritual quest.

As the spiritual quest genre suggests, people are compelled to journey (Cambell, 1968; Dispenza, 2002; McAvoy \& Dustin, 1989). Fredston (2001), unbeknownst to her, first felt the call to journey by boat at the tender age of ten while living on Long Island Sound not far from New York City.

I launched my boat, clambered in, and rowed away to a new freedom...I made the seven-mile crossing to Long Island... On the way home and scarcely a mile from Larchmont Harbor, we were stopped by the Coast Guard. A pockmarked, humorless man in an orange jumpsuit asked our ages, carefully logged our names and addresses onto a clipboard, and called our parents. It hadn't occurred to us to think about the distance or the danger. We were simply heading for another shore, propelled by a spirit. (p. 5)

Fredston was often called to the "sound" during her young years, and she admits that she was not like the others in her family, such as her distinguished lawyer father, as she 
gravitated to nature instead of to the mall. She described herself as "a stick-figured brat," a "nonconformist from an early age," "stubborn," and "allergic to criticism." She proclaimed that she was given every opportunity as a child, such as regular piano lessons, good cooking, and hours of tennis lessons. But her row boat continued to call and compelled her to leave the manicured lawns for the mysteries of the ocean. She proclaimed that "I sensed the potential of using my own power to compose life. Ikky Kid [her row boat] floated me into wider horizons, away from my circle of competitive, achievement-oriented friends, giving me room to find good company in myself and nature" (Fredston, p. 6).

Years later, Fredston and her husband accepted the call every summer to journey and disappear into the northern Arctic waters of the world to find solitude and to rejuvenate the spirit. However, like the quest genre suggests, in following the call to journey, one must prepare and train for the task ahead. Fredston began her training at the age of ten when she rowed her small boat all around Long Island Sound against the wishes of the Coast Guard and her parents. She continued her life-long training during her teen years by going to a ranch camp in Wyoming, participating in a National Outdoor Leadership School (NOLS) wilderness skills course, and interning with the National Park Service as a summer naturalist at the Grand Canyon. Additionally, she participated in a second NOLS sea kayaking course in Alaska's Prince William Sound. During her college years she continued her training and joined the crew team where she competitively raced at the collegiate level. "Rowing at very competitive levels means at least three hours of training every day. It means long hours in the weight room and on running trails" (Fredston, 2001, p. 11). 
During adulthood, she continued her preparations. She realized that to do the journey her way, kayaking was not for her. She enjoyed rowing not paddling. However, there were no boats suitable for long-distance ocean rowing. Therefore, she and boat designers spent considerable amounts of time and money designing and constructing a boat to fit her specific needs and desires. Additionally, there were countless other facets of the journey to find solutions to besides physical conditioning and boat building.

At almost every turn, there was something to figure out - what shape hull would best grip the side of a mountainous swell, how to pack gear for a hundred days, how to do surf landings, how to keep mind and body going when terrified, bored, or bones-to-dust exhausted. (Fredston, 2001, p. 28)

As McAvoy \& Dustin (1989) suggest, a helper/guide usually emerges to help the wouldbe hero. Many helper/guides emerged during this preparation time to help Fredston prepare for her journey and provide her with the necessary skills, equipment, and logistical information to construct her journey.

The quest genre suggests that many journeyers are considered anti-social and may not bend to the conformities of society. Christ (1980) suggests that women in particular often find it difficult when choosing a path that does not conform to traditional female gender norms or when they seek outside traditional roles for meaning and fulfillment. Fredston (2001), too, had to justify her need to travel to many of her friends and family who rejected the idea of a nonconventional life:

Most often, though, people question why we undertake these trips at all. They might as well ask us why we breathe or eat. Our journeys are food for our spirits, clean air for our souls. We don't care if they are firsts or farthest, we don't seek sponsors. They are neither a vacation nor an escape, they are a way of life...we do these trips because we need to. ( $p$. $\mathrm{XV}$ ) 
Additionally, Fredston encountered many people who did not understand her as she focused on her quest above all else in life. It was difficult for her and her questing to remain unnoticed because the symbols of her journey were visible for all to see:

Any prolonged rowing causes a marked physical metamorphosis...I end a trip with my stomach muscles bunched in six neat compartments, hands as tough as walrus hide, sculpted shoulders, and a back that looks as if it has been implanted with bicycle tubes paralleling my spine... Once, at a resort on the Alaska Peninsula, I was introduced to a florid-faced oil executive from Texas with initials for a name. He recoiled when we shook hands and looked at me as though I'd jetted in from Mars with the express purpose of horrifying him. 'Honey', he said, 'no woman deserves hands like that'. (pp. 18-19)

There were many instances during the preparation stage, journey, and after when

Fredston had to justify the purpose of the trip as well as the many sacrifices that she and her husband made. Many people were concerned about the physical dangers of the journey, including death. Others mourned the loss of financial gain and the sacrifice of material possessions and comforts that were lost due to the journey because each summer instead of working and making money, they chose to row. To provide the food, gear, and transportation by plane to many of the Arctic countries, they saved what little income they made during the winter instead of conforming to the materialistic and consumptive norms of American society. Fortunately, Fredston had a husband that not only supported her nonconformist lifestyle and her spiritual quests, but also participated and agreed with her nontraditional ideas.

The quest genre suggests that the journey is not just a trip, but an experience of entering into a new and different world (Campbell, 1968; McAvoy \& Dustin, 1989). Fredston (2001) gives a clear example of how her journey takes her far from her daily life and into a new world: "The instant you slit the water, you have entered a different world. 
The deeper you descend, the more completely the din fades away and the more aware you are of your own suspended breath" (p. 61). It appears that through traveling and rowing, Fredston not only traveled into a new and different physical world, but she traveled deeper into herself. She became aware of even her breath.

The quest genre describes journeys as a form of emptying through simplicity and the trials of hardships and danger (Campbell, 1968; McAvoy \& Dustin, 1989). This emptying helps prepare one to be open to spiritual experience. Some of the harsh realities of Fredston's journey included the need to find a suitable setting to pitch their tent and the challenges of cooking their food over a small burning stove in difficult weather. Their journey was not always safe. They survived mountainous seas, hurricane-force winds, grizzly and polar bear attacks, and frozen water in which they had to drag their boats across jumbles of ice. The physical and mental exertion needed to survive in the Arctic was acknowledged as an integral part of their spiritual journey. Every summer they knew that they would encounter physical danger as well as mental depletion. However, Fredston (2001) illuminates the benefits of emptying:

As individuals, our most vulnerable inner core is usually carefully sheathed by bravado, pretension, and assumptions. Coping with agitated cold water by day and bad-tempered bears by night is a sure, though not necessarily recommended, way to accomplish a kind of metaphorical skinning. Hardship strips us to little more than pink flesh. For better or worse, the raw fibers of which we are made then lie more clearly exposed. (p. 109)

Emptying through hardship opens people to new thoughts and spiritual experiences. "When people comment wistfully that rowing must give me time for intense introspection, I usually reply, 'Yes...', letting my voice trail off in a way that implies a subject too fathomless for brief conversation. How can I explain that I treasure these 
trips for the focus that comes with simplicity?" (p. 62). She also spoke of self-mastery through hardship.

We were often told, 'You are very brave to live in nature.' The implication was that we needed courage to master the storms, the sudden winds, the torrential rains, and the big seas. But these are things that can never be mastered. If what we do has required any courage at all, it is in attempting to master ourselves. (p. 28)

To survive the dangers and physical hardships of rowing through the Arctic, complete focus of the task at hand was required. Intense focus led Fredston to revel in the knowledge that life is lived in such moments and thus she gained a greater consciousness of life itself.

Fredston (2001) characterized her spiritual attainment as a connection to something larger and outside of herself (Bloom; 2007; Chenery; 1984; Christ; 1980; Driver et al., 1996; Fox, 1999; Kaplan \& Talbot, 1983; Kass et al., 1991; McDonald, 1989; McDonald et al., 1988; Stringer \& McAvoy, 1992): “Travel takes us outside ourselves and deeper within. It reminds us that despite geographic vastness, all places are connected to others, with simple elements like air and water in common" (Fredston, 2001, p. 139). It is important to note that through cultivating a feeling of connection to nature and becoming part of it through journeying, her spiritual attainment was realized: "In the process of journeying we seem to have become the journey, blurring the boundaries between the physical landscape outside ourselves and the spiritual landscape within" (p. xvi).

It is apparent through a close analysis of Fredston's (2001) travel narrative that spirituality was a motive for engaging in adventure travel. Because of the spiritual attainment she gained, she chose to engage in adventure travels every summer, year after 
year. Adventure travel, specifically Arctic Ocean journeys, was a vehicle to spiritual attainment and this experience was narrated through the quest genre.

Fletcher: The Man Who Walked Through Time

A second adventure travel narrative that illustrates the spirituality of adventure travel in the form of the quest narrative is the story of the first man to walk the length of the Grand Canyon below the rim.

The Grand Canyon of the Colorado is a chasm that slices through the plateau country of northern Arizona like a gigantic and impossible desert crevasse. It is more than two hundred river-miles long. At its center, it is over a mile deep: if you built four Empire State Buildings in it, one on top of the other, they would not rise level with the Rim. The Canyon averages ten miles across, but some of its bays swing back for twenty, thirty, even forty miles. In all it covers more than one thousand square miles. But the vast bulk of this area is almost never visited. Even today, unexplored corners remain. (Fletcher, 1989, p. 3)

As in all quests, the traveler feels the call to journey. Fletcher (1989) described that he felt the call "quite unexpectedly, the way the big moments often do" (p. 5). He and a friend were on a cross-country driving trip and decided to take the long way for a quick glimpse of the Grand Canyon. As they approached the rim, he explained that all of the pictures, photographs, and descriptions of the Grand Canyon had not prepared him for the depth of cliffs, buttes, hanging terraces, and intricate patterns and fusion of colors. The experience of the Canyon was profound and life changing. "In that first moment of shock, with my mind already exploding beyond old boundaries, I knew that something had happened to the way I looked at things" (p. 6). He decided that walking the canyon, in unexplored places far from civilization, would increase his ability to see things differently. The potential of the canyon called to him. "It was mysterious and terrible-and 
beckoning. And some time during the afternoon, as I sat on the brink of this strange new world, it came to me that if a route existed I would walk from one end of the Canyon to the other" (p. 6).

After he felt the call to journey the Canyon on foot, he spent a year in preparation. He began his preparation the very same day that he felt the call. He visited the National Park Visitor Center and learned that people had run the river in boats but no one had "forced a passage of the Canyon on foot" (Fletcher, 1989, p. 7). It is important to realize that there is no trail that runs along the bottom of the Canyon beside the Colorado River. Instead, steep cliffs on either side of the river rise thousands of feet up with no purchase for feet. Hence, one must find a route along "steep hanging terraces...I should explain that they are narrow, steeply sloping ledges that often extend for mile after mile after mile as precarious steps between successive cliff faces" (p. 7). Not only would forging a route through unexplored territory be a challenge, but so would finding enough water to survive. Rarely is there water on the hanging terraces, and steep impassable cliffs separate the hiker from the river. There was a very real possibility that he could, as others before him had, die of thirst well within sight of the unreachable river far below. So the primary component of his preparation was research about the area he would trek.

In the final month of the year of waiting, with preparations mounting to their inevitable climax, every day pulsated with problems: Grappling with huge, multiple-minuscule issues of what equipment to take and what to leave behind. Deciding what to do about such hazards as rattlesnakes, scorpions, and twisted ankles miles from water. (p. 12)

During the phase of preparation, several helper/guides emerged to provide information and ideas to survive this unknown terrain. 
As the quest genre suggests, oftentimes journeyers are anti-social and solitary figures. Fletcher was no different. He sought the silence and solitude of the Canyon. Within the emptiness of the Canyon he hoped to answer life's biggest questions, to feel connected to something outside of himself, and to feel part of the world instead of just living within it. He sought a deeper connection to himself and to life. Fletcher was seeking a spiritual experience. As he journeyed from the rim, the top of the Canyon, and descended through the layers of time to the bottom, he realized that he may have found an environment that was compatible with his goals.

For I knew now that I had left behind the man-constructed world. Had already escaped from a world in which the days are consumed by clocks and dollars and traffic and other people. Had crossed over, at the moment I came to the sandstone platform, into a world that was governed by the sun and the wind and the lie of the land. (Fletcher, 1989, p. 17)

In this world filled with nature, he followed a similar pattern as the quest genre suggests. The cares of the secular world began to fade away within the openness of the desert. His story echoed the theme of emptying to prepare the way for a spiritual experience. "Soon I was feeling grateful too for the familiar rewards of simple living - for the cleansing primitive habits and precautions" (p. 17). As the monks of old who lived a simple life of moderation, so did Fletcher as all his material possessions were carried on his back and he learned the satisfaction and empowerment that came with living with less and being filled by that which is real and meaningful. "You know of course, that you are going to renounce the complexities of civilization and embrace the simple life. And you know that the simple life can lead to insight" (p. 27). This contrasts with much of contemporary North American society - a society that is filled with longing for material possessions and a continually escalating consumerism. It is suggested that natural environments are 
very compatible with spiritual quests; therefore, many seekers perform their quests within natural or wilderness environments (Christ, 1980; McAvoy \& Dustin, 1989).

The days of his journey were filled with practical concerns such as finding a safe route from one terrace to another and finding water. Sometimes the need for water forced a wait near a stream until a rain created life-sustaining pockets of water, which unfortunately started to evaporate the moment they filled. Fletcher (1989) described a day when he had to walk from one source of water to the next in a limited amount of time. He was concerned that the terrace would not continue to the water source, but that it would give out and he would have to turn back and retrace his steps back to his starting point and water. His greatest fear was that the terrace would end far away from the beginning and he would not have the time or strength to return to safety, but would become stranded far from water and help.

Because few people had hiked the canyon, he had very little information from which to choose a correct route. Route-finding through critical areas was the biggest trial of the journey. He explained a harrowing experience:

The Esplanade, for all its flat and open aspect, is a maze. All along it you face a choice of two routes: rock terrace or talus. The rock terraces mean relatively level going, and they often open up into broad boulevards. But they are not only consistently serpentine...they also keep petering out. And then you have to decide whether to climb ten, twenty, or thirty feet up or down onto the next ledge. You base your choice on the look of the ledges on the far side of the subcanyon you are zigging and zagging along. And this raises one of the scale problems that the Canyon is always posing. A rockface that from a distance looks like something you might have to lift your pack over turns out to be as high as a house. As compensation, though, a ledge that promises no more than a handhold may be wide enough to drive a bus along.

But at each major canyon head the rock ledges vanish. Rubble from the cliffs has spilled down over the bedrock. To cross these steep talus slides at the least horrifying places you have to climb high and on the 
far side of the canyon head you find yourself part way up the talus that always skirts the cliff. (Fletcher, 1989, p. 74)

The journey was not always hard for Fletcher. Along with trials were moments of spirituality. The magnificent red rocks were a power that separated him from lifesustaining water, yet they also had the power to inspire and to teach the meaning of life as well as display the connection of life through the layers of time.

Now, every sunlit desert morning has a magic moment. It may come at five o'clock, at seven, or at eleven, depending on the weather and the season. But it comes. If you are in the right mood at the right time you are suddenly aware that the desert's countless cogs have meshed. That the world has crystallized into vivid focus. And you respond. You hold your breath or fall into reverie or spring to your feet according to the day and the mood. (Fletcher, 1989, p. 92)

As his journey progressed, these types of experiences occurred more often and with greater intensity. He began to describe himself as being 'knifed-edged alive' and at the 'peak of awareness.' Because of increased awareness he began to perceive and experience the environment more fully, and he noticed connections and patterns that otherwise he would have been blind and deaf to except for his emptying through trial. He explained his spiritual experiences as:

I thought very much about this intricate web-in-time: I felt it. Felt myself an integral part of everything that went on around me. Felt it with a simple and straightforward certainty I had never known before. Felt myself not only as a part of the web of life as it happened to exist in the present, but as a part of the throbbing, pulsating process that is all we know. A process of which this present web is merely a fingerprint. (Fletcher, pp. 136-137)

Walking the Grand Canyon, an adventure travel experience, provides another example of a spiritual quest. As the genre suggests, he felt the call to travel, prepared for over a year, and embarked on a journey. The journey provided a cleansing and emptying experience 
through trials, obstacles, and the need for simple living, thus providing the opportunity

for spiritual attainment. Fletcher's (2001) A Walk Though Time is a classic spiritual quest.

\section{Mustoe: Lone Traveler: One Women, Two Wheels and the World}

A third example of adventure travel as a spiritual quest is Lone Traveler: One

Woman, Two Wheels and the World (Mustoe, 2002). It is a story of a sixty-year old retired London headmistress of a girls' school. It is important to realize that adventure travel, specifically hard adventure travel, is not just for the young and daring males of the world as some still suggest (Travel Industry Association of America, 1998). But a retired 60-year-old woman may also choose to give up her world of luxury, security, and ease to embark on a journey of spiritual discovery. Like the quest genre suggests, great journeys are hard. They are often filled with discomfort and danger. This story has both.

The theme of simplicity and the simple life permeate Mustoe's story. She constructed a simple life bicycling around the world.

I discovered that cycling was the perfect way to travel. It was faster than walking, but slow enough to appreciate all the sights and scents of the countryside. With no possessions to speak of, no complicated mechanism to go wrong and no timetables, my days were wonderfully carefree and my only duty in life was to get myself safely from one shelter to the next before nightfall. Everything I needed was to hand, in two small bags on the back of the world's greenest and most energy-efficient machine. My life was simplicity itself. After years of responsibility, I just couldn't believe my luck. (Mustoe, 2002, p. 1)

Her journeys did not begin until later in life, but her call came early. She explains that her love for solitary travel began serendipitously at the age of fifteen when she "got caught up in a rail strike" (Mustoe, 2002, p. 31). She was on her way from London to spend Easter with a former French exchange student in Bordeaux, France. By the time 
her train finally arrived at its destination, her exchange family had left the train station.

They had no way to contact either Mustoe or her parents because this was the era before

the average person had a telephone. Mustoe did not have the address of her exchange

family, so she found a room with two other stranded English girls and began her "magical

week" alone in France with no parents or guardians:

The Metro was free, as the ticket-collectors were on strike, and the Army had been called in to service the suburbs, so I could travel anywhere I liked in the city, without counting the cost. I tramped the streets and museums of Paris till I dropped and rode to Versailles in the back of an Army lorry. I lived on bread and chocolate, sat in cafes, dressed as I pleased, strolled through Pigalle and stayed out till midnight — all the things I should never had been allowed to do at home. It was my first real taste of freedom. (p. 31)

It appears that as an adult, she tried to capture that first experience of real freedom by traveling the world on her bicycle. From her narrative, travel seems to be a means to create opportunities and the freedom to experience more than a traditional life bound by the norms of society.

No solitary journey since has quite matched the exhilaration of that first trip. Boarding the Heathrow bus on a frosty morning for a flight to the tropics, or slipping the car into gear and pointing the bonnet to Dover are still high on the list of excitements. But the nearest thing to those heady days in Paris is loading up one of my bicycles and cycling off alone into freedom and anonymity. No schedule, no holiday address, no telephone numbers. I go where the fancy takes me and all possibilities are open. (Mustoe, pp. 31-32)

Preparation follows the call to leave. Preparation is the stage that makes the journey and the quest possible. Mustoe explained her preparation stage and its necessity in great detail. She also included helpful tips, including an appendix of her luggage list, for those who may be inspired from her own story to embark on a quest of their own. It seems that she may be a helper/guide for others seeking to replicate her experience. 
So many people have asked me how I go about planning a long trip and how I organize my life when I'm far away from home... The first essential is meticulous planning...Packing for a bicycle-ride is a particular challenge, as two small panniers leave little room for error or frivolity. (Mustoe, 2002, p. 7)

Everything that she needed for both survival and comfort had to be packed in two small bags that ride on either side of her bicycle. In addition to physical space, weight was also a consideration because Mustoe did not choose her routes based on ease, but on historical routes that took her through jungles, deserts, and over the highest and roughest mountain ranges in world, including the Himalayas. She had to carry the weight of each item that she packed.

About a week before I leave on a trip, I lay out on my spare bed all the items I'm thinking of taking, and I'm usually horrified when I see the size of the pile! I go and look through it every day, subtracting a pair of socks here and a book there. By the end of the week, it's amazing how the pile has shrunk and how easily I can fit the remainder into my panniers. (Mustoe, p. 9)

Planning her routes was another major part of the preparation stage. She did not just set out without thought and hope to find a place to sleep for the night or a store to buy a meal. She spent days and weeks pouring over maps picking routes that facilitated the type of experience that she sought.

To add an extra dimension to my travels, I followed historical routes around the world: the Romans, Alexander the Great, the Moguls, the British Raj and the North American settlers. Old roads echo with the footsteps of those who have trodden them throughout the ages, and to ride those roads slowly and sometimes painfully on a bicycle is to get a glimpse of the struggles, the hopes and the dreams of the people who built our world. On a practical level, the old roads are comfortable. Unlike modern motorways, which stride over hill tops, bridge rivers and gorges and tunnel under mountains in dazzling feats of engineering, the old roads meander along valleys and take the gradients gently, with due regard to the frailties of the men and beasts of burden who have to use them. (Mustoe, 2002, pp. 1-2) 
Not only did Mustoe choose historical routes that whisper of times past, she chose to bike her routes at the time of year that was most conducive to safety and pleasure. She did not travel the world to punish herself, but to truly live life and to live the best way possible. She explained that:

I'm a fair weather cyclist, so I plan my seasons as carefully as my routes. Some cyclists belong to the school of endurance, even masochism, but I cycle for pleasure. I don't go out in the rain, snow or searing heat if I can avoid it. I've never understood why Dervla Murphy chose to cross Europe in the depths of winter, then boiled through the Persian summer. Europe in spring is delightful and the Eastern autumn is sunny and dry. She could have had beautiful weather throughout, if she'd started a few months later. (p. 9)

Mustoe differs a bit from the adventure journeyers that have been discussed above. She did not physically train before the journey. Instead she preferred to "train on the journey, doing shorter distances at first and gradually building up to my normal $80-100 \mathrm{~km}$ a day" (pp. 12-13). However, she learned the languages of the countries in which she visited, decided what route to bike and when, and what to bring and leave behind, then trusted that the rest of the journey would take care of itself. She believed that most people in the world are kind and that most problems would be solved along the way. She tried not to worry about what would happen and reminded friends and family who had worried for her safety that she could get mugged in London as easily as in any other country. She also reminded them that traveling by car is just as dangerous as, or more so, than biking along the same road. She admonished that what she learns and experiences more than makes up for what she sacrifices by living out of two panniers attached to her bicycles.

She, just as the quest genre suggests, often needed to justify her lifestyle of traveling to both friends and strangers. She described experiences where hotel managers 
chastised her for "Cycling all that way! What a stupid thing to do" (Mustoe, p. 2002, p.

20) and where she had to explain that:

Fear is irrational. Though a pre-dawn arrival is just as dark as a late evening one, it has an entirely different feel to it. When I got off the bus in Cajamarca, high in the Cordillera Central, it was 3 a.m. The bus station was a dirt yard on the outskirts, with no waiting-room, so I had to move into the city. A mysterious stranger swathed in shawls and scarves approached me with great gallantry and offered to escort me to my destination, but I didn't know where I was going. I pedaled off alone. The hotels were all bolted and barred, so I cycled slowly round the frosty city, waiting for it to come to life. It was a magical night. Moonlight and brilliant Andean stars lit up the rich facades of the churches, throwing their intricate stone carvings into high relief, and topiary bushes cast fantastic shadows across the monumental main square, the Plaza de Armas. Without people or traffic to link me to the twentieth century, I drifted down the cobbled Spanish alleyways into a dreaming time-warp. Strangely, I wandered through the deserted city, in a foreign land with a reputation for violence, and yet I never felt a moment's anxiety. It was all so beautiful in the silence, as unreal as a Baroque stage-set, and fear was somehow inappropriate. (pp. 20-21)

Her journey, the quest, is best described in her own words. At first glance the journey seems simple and to lack the explosion of something remarkable. But what she seemed to find is a spirituality that can only be found on the road and in the space of solitude that allows the freedom of time and lack of insignificant obligations that take up the days of an ordinary life. It will be apparent from her own words that Mustoe's spiritual attainment is feeling a part of something bigger than herself and feeling connected to something outside of herself. Her spiritual attainments frequently manifest themselves as a re-prioritization of goals and values such as a shift to a simpler, less harried, less anxious, and more reverent (Woodruff, 2001) lifestyle.

Traveling on a bicycle brings awareness of every gradation in tone, every shift of light. There are changes in perspective too. A snow-capped mountain comes into view in the far distance, moves slowly alongside and finally disappears behind me, in counter point to my own forward motion. I creep across vast empty landscapes feeling no larger or more significant 
than an ant. There is nothing like the immensity of a desert for cutting human beings down to size, except perhaps the open sea. (p. 79)

Trials help her find the marvel in simplicity. The trials, as the quest genre suggests, provide an experience of emptying, thus allowing the preparation and space for new experiences and spiritual attainment. One trial that Mustoe (2002) experienced was the wind:

It started as a stiff breeze from the west and gathered strength so swiftly that within moments it was raging through its valley funnel in a tide of sand and litter. I watched with awe from my bedroom window as the poplars bent almost double and the railway line across the road disappeared completely in a cloud of flying dust. It was all over in two hours, but as a foretaste of things to come, it filled me with dismay. No one, however, strong, could possibly cycle against such elemental frenzy, and it was going to be my adversary for the next 5,000 km. (p. 98)

The second type of trial that tested her ability and opened the way for spiritual attainment were the mountains of the world. From struggling up the passes she learned to appreciate the downhills and other luxuries of the world which are often taken for granted. She learned not only how little one really needed to survive but how little one needed to be blissfully happy.

The wind raged and the sleet up there turned to blizzard. I used my sunglasses as goggles to protect my eyes from sharp, blinding snow, and wore every garment I possessed, even my smog-mask on top of my balaclava, yet I still shuddered with cold. My hands were so frozen on my handlebars that I was seriously afraid of frostbite and had to keep stopping to stick them up the front of my anorak and jumper to bring them back to life. I have no idea of the altitude of those passes. (p. 100)

Throughout her journey, evidence of her spiritual attainments is explained. They are often found within a simple setting after a grueling day pedaling up high mountains, through harsh bitter winds, or both. But such statements as, "I had a sudden flash of awareness. It was one of those rare moments when I was supremely happy and knew it. 
There was nothing on earth I would rather be doing and nowhere I would rather be"

(Mustoe, 2002, p. 158), provide clues that she was achieving a more simple reverent life.

The last chapter of her book is entitled "Lessons." This chapter summed up her spiritual attainments:

Travel for me has been a change of soul. Or, to put it less poetically, travel has changed many of my attitudes. It has given me such a different perspective on life that I've almost become a new person.

Take possessions. When I cycled away from the champagne sendoff on my first ride round the world, I was cycling away from an affluent lifestyle - a large headmistress' house in Suffolk, a London flat, an Alfa Romeo, suits from Hardy Amies and the best Italian shoes. My bicycle had two rear panniers and a handlebar bag. For the next fifteen months, everything I had in the world would be carried in those three bags. In one afternoon, I'd reduced my resources from easy abundance down to bare essentials. It was 'downshifting' with a vengeance... a month into my ride, I realized what a liberation it was to be free of all those possessions.

Possessions eat up our money and our time. They dominate our lives. We save up for them, struggle round the shops to find them; and when we've got them, we have to clean them, mend them, take them to be serviced, insure them and eventually buy a bigger house to put them in. All this expense - and they're only things...

These difficult journeys have put my priorities into order. First come water and second comes a safe place to spend the night. Food comes a poor third. Most westerners overeat and carry enough surplus fat to survive for a few days on short rations. (pp. 209-210)

To further illustrate her spiritual attainments she repeated the theme of downshifting and ended her entire travel narrative with the following: "Which brings me back to possessions and to all the people around the world who have taught me how few of them we really need. As Socrates once said, 'What a lot of things I can do without!'” (p. 215).

\section{Discussion}

The close examination of three adventure travel narratives illustrates the pattern of a spiritual quest genre. The major steps of the quest are the call to journey, preparation 
for the journey, the journey, and the return home (Campbell, 1968; Dispenza, 2002; McAvoy \& Dustin, 1989).

All travelers discussed in this paper, whether young or old, male or female, felt the call to journey. Fredston (2001) felt her call from a very young age while rowing a small boat in Long Island Sound and reveling in the freedom that rowing created. This yearning for freedom influenced many of her future choices as she unknowingly began to prepare for her adult life of rowing the Arctic waters. Fletcher (1989) first felt his call to journey the moment he laid eyes on the Grand Canyon. It was a life-changing experience that shifted his perspective of the world and his place in it. He began preparation that very same day. Mustoe (2002) first felt the call to journey when she was fifteen and stranded alone in a foreign town. Instead of feeling fearful and anxious, she felt free and excited. That first experience of freedom and exhilaration was a touchstone throughout her adult life and career until she dropped out of normal society to bike around the world indefinitely.

From the moment the call to journey was answered, all three travelers' lives altered direction and became focused on the task ahead. Their days were spent in preparation for the journey by training physically and mentally, researching routes to follow, determining how to provide for survival, and saying goodbye to those in their life. Fredston (2001) trained for her journey from the tender age of ten. She continued her physical and skill training through athletics, college, and jobs where it culminated in her first Arctic journey. Fletcher (1989) spent his days preparing by gathering gear and researching traveling routes and water holes. Mustoe (2002) researched historical routes to complement the weather and gather the gear to see her through her journey. 
All of the travelers' journeys were composed of physical trials to surmount and emotional upheavals to push through. Fredston (2001) endured bitter cold in the Arctic wilderness while sleeping in a tent, cooking on cold bare rocks, and kayaking through Arctic seas filled with icebergs. She also battled the constant uncertainty of weather, polar bear attacks, and the knowledge that the ice may freeze around her forcing her to pull a fully loaded kayak across the jumbles of ice. Fletcher's (1989) trials were more mental in nature than physical. He dealt with the constant stress of finding water and navigating the maze of terraces, whereas Mustoe (2002) had to overcome high mountain passes, strong relentless winds, and extreme high and low temperatures.

Spiritual attainment was achieved through emptying and cleansing through trial. Some forms of spiritual attainment were feeling part of something bigger than one's self and feelings of awe. Fredston (2001) described feeling connected to nature but more importantly to her self. Her self-awareness increased. Fletcher (1989) felt connected to the great web of life and felt a part of everything. Fletcher, like Fredston (2001) and Mustoe (2002), also felt an awaking and a deepening of his self-awareness. Mustoe’s strongest spiritual attainment manifested as a reprioritization of goals and needs. She understood how little she needed to live and be happy. All three travelers' spiritual attainment resulted in a deeper understanding of self, a spiritual connection to nature, and an understanding that simplicity and lack of material possessions leads to happiness.

Through adventure travel as a spiritual quest, the travelers redefined their meanings of what composes a successful life and how little material wealth they needed to be happy. All gained a greater awareness of life; they learned to both live in the moment and live a more reverent and spiritual life. It is important to note that reverence 
is a virtue that crosses the boundaries of culture and time. Reverence is not dependent on religion, although those who are religious may experience it. "Reverence begins in a deep understanding of human limitations; from this grows the capacity to be in awe of whatever we believe lies outside our control" (Woodruff, 2001, p. 3). Feelings of awe and the cultivation of reverence for life and humanity increases the harmony of the soul, unifies societies, and directs decisions that will aid in the common good. Therefore, it is important to understand the relation between spiritual questing and adventure travel and to also acknowledge that spiritual questing may be a primary motive for adventure travel.

It is apparent that adventure travel narratives are a part of the quest genre and are spiritual quests; however, how does the spiritual quest illustrated in adventure travel narratives influence the perspectives of its readers? How do the spiritual quest narratives frame adventure travel expectations of readers and potential adventure travelers? Are people who are yearning for their own spiritual awakening influenced by adventure travel narratives? Are they influenced to the extent that they embark on their own journey?

Christ (1980) suggests that women need stories of spiritual quests to act as a framework of support and to provide direction. Women experience spirituality different from men, yet historically stories have been masculine and patriarchal in nature. However, this paper presented three adventure travel narratives of which two were written by female authors. They constructed their narratives in the structure of a quest and did not differ from the narrative written by a male author. However, it may be relevant to note that McAvoy \& Dustin (1989) suggest all humans, regardless of sex or gender, are "compelled to seek out adventure, to nurture heroic qualities" ( p. 41). Future 
research should examine whether there is a difference between female and male authors regarding the adherence to the quest genre.

Additional research should focus on the extent to which adventure travel narratives reflect the reality of the adventure experience. How much of the actual travel experience is edited to fit into the quest genre? Does this genre reflect reality or the tradition of the travel myth? For those narratives that do not fit the quest genre, is this a reflection of active nonconformity or the reality of an adventure experience that truly differs from a quest? Also, does the travel motive influence the structure of the travel experience?

Because travel narratives have the ability to frame future travelers' expectations and influence trip destination choice, travel style, and even intention to travel (Clough, 1997; Dann, 1996, 1999; Wilson \& Richards, 2004), it is important to understand how the illustration of the quest genre as a spiritual metaphor influences readers. Do readers expect a spiritual experience if they attempt to replicate that experience? If there is a disconnect between actual travel experiences and the published narratives that describe them, should the reader be aware of this fact? There are still many questions and concerns regarding the influence of the adventure travel narratives as an illustration of a spiritual quest on its readers and the travel and tourism field. 


\section{References}

Bloom, K.S. (2007). Exploring wilderness as spiritual content and process: The construction and preliminary validation of the Wilderness Spirituality Scale. Unpublished doctoral dissertation, University of Utah, Salt Lake City.

Borella, S.S. (2006). The travel narratives of Ella Maillart: (En)gendering the quest. New York: Peter Lang Publishing.

Bryson, B. (1997). A walk in the woods. London: Transworld.

Campbell, J. (1968). The hero with a thousand faces. New York: Princeton University Press.

Chenery, M.F. (1984). Nurturing the human spirit in camping. Camping Magazine, 57(1), 21-28.

Christ, C. P. (1980). Diving deep and surfacing. Toronto, ON: Beacon Press.

Dann, G. (1996). The language of tourism: A sociolinguistic perspective. Wallingford, UK: CAB International.

Dann, G. (1999). Writing out the tourist in space and time. Annals of Tourism Research, 26(1), 159-187.

Dispenza, J. (2002). The way of the traveler. Emeryville, CA: Avalon Travel Publishing.

Driver, B.L, Dustin, D., Baltic, T., Elsner, G., \& Peterson, G. (1996). Benefits of leisure. State College, PA: Venture

Ewert, A., \& Hollenhorst, S. (1989). Testing the adventure model: Empirical support for a model of risk recreation participation. Journal of Leisure Research, 21(2), 124139. 
Fletcher, C. (1989). The man who walked through time. New York: Random House.

Fox, R. (1999). Enhancing spiritual experiences in adventure programs. In J.C. Miles \& S. Priest (Eds.), Adventure Programming (pp. 455-461). State College, PA: Venture Publishing.

Fredston, J. (2001). Rowing to latitude: Journey along the Arctic's edge. New York: North Point Press.

Fullagar, S. (2001). Embodied affect in Alphonso Lingis' travel writing. Tourism Studies, 1(2), 171-183.

Gelman, R.G. (2001). Tale of a female nomad: Living at large in the world. New York: Three Rivers Press.

Griffith, D., \& Albanese, P. (1996). An examination of Plog's psychographic travel model within a student population. Journal of Travel Research, 34(4), 47-51.

Groom, E. (Ed.). (2005). Methods for teaching travel literature and writing: Exploring the world of self. New York: Peter Lang Publishing Co.

Hill, B.J., (1995). A guide to adventure travel. Parks and Recreation, 30(9), 56-65.

Jensen, C. (1985). Outdoor recreation in America $\left(4^{\text {th }}\right.$ Ed). Minneapolis, MN: Burgess Publishing Company.

Kaplan, S., \& Talbot, J.F. (1983). Psychological benefits of a wilderness experience. In Altman \& J.F. Wollwill (Eds.), Behavior and the natural environment (pp. 163203), Human Behavior and the Environment series, vol. 6. New York: Plenium.

Kass, J.D., Friedman, R., Leserman, J., Zuttermeister, P.C., \& Benson, H. (1991). Health outcomes and a new index of spiritual experience. Journal for the Scientific Study of Religion, 30(2), 203-211. 
McAvoy, L.H., \& Dustin, D. L. (1989). Resurrecting the frontier. Trends, 26(3), 40-42.

McDonald, B.L., Guldin, R., \& Wetherhill, G.R. (1988). The spirit in the wilderness: The use and opportunity of wilderness experience for spiritual growth. In H.R. Freilich (Comp.), Wilderness benchmark 1988: Proceedings of the National Wilderness Colloquium (Gen. Tech. Rep. SE-51) (pp. 193-207). Asheville, NC: USDA Forest Service, Southeastern Forest Experiment Station.

McDonald, B.L., \& Schreyer, R. (1991). Spiritual benefits of leisure participation and leisure settings. In B.L. Driver, P.J. Brown, \& G.L. Peterson (Eds.), Benefits of leisure (pp. 179-194). State College, PA: Venture.

Mustoe, A. (2002). The lone traveler: One woman, two wheels and the world. London: Virgin Books Ltd.

Palin, M. (1997). Full Circle. London, UK: BBC Books.

Plog, S. (1991). Leisure travel: Making it a growth market...again! New York: John Wiley \& Sons.

Priest, S. (1992). Factor exploration and confirmation for the dimensions of an adventure experience. Journal of Leisure Research, 24(2), 27-139.

Robinson, D. (1992). A descriptive model of enduring risk recreation involvement. Journal of Leisure Research, 24(1), 52-63.

Stringer, A., \& McAvoy, L. (1992). The need for something different: Spirituality and wilderness adventure. The Journal of Experiential Education, 15(1), 13-20.

Sung, H., Morrison, A., \& O’Leary, J. (1996). Definition of adventure travel: Conceptual framework for empirical application from the providers' perspective. Asia Pacific Journal of Tourism Research 1(2), 47-67. 
Quest Genre as Spiritual Metaphor in Adventure Travel Narratives 37

Thursby, J. S. (2005). American travel literature in the classroom: Inward and outward journeys. In E. Groom (Ed.), Methods for teaching travel literature and writing: Exploring the world of self (pp. 31-42). New York: Peter Lang Publishing.

Travel Industry Association of America (TIA) (1998). Adventure Travel Report 1997 (February).

Wilson, J., \& Richards, G. (2004). Backpacker icons: Influential Literary 'Nomad' in the formation of backpacker identities. In G. Richards \& J. Wilson (Eds.), The global nomad: Backpacker travel in theory and practice (pp. 123-148). Clevedon, UK: Channel View Publications.

Woodruff, P. (2001). Reverence: Renewing a forgotten virtue. Oxford: Oxford University Press. 